\title{
DEVELOPMENT OF BEE COLONIES BASED ON EARLY SPRING FEEDING ACCORDING TO THE DEVELOPED SCHEME
}

L. O. ADAMCHUK, Candidate of Agricultural Sciences, https://orcid.org/0000-0003-2015-7956

Department of Horse-Breeding and Beekeeping,

S. V. BOIARCHUK, Candidate of Agricultural Sciences, https://orcid.org/0000-0002-8256-850X

Department of Animal Nutrition and Feed Technology to them P. D. Pshenychnogo,

K. V. LAVRINENKO*, postgraduate student of the Research Institute of Technology and Quality of Animal Products, https://orcid.org/0000-0003-1033-6811

R. M. DVYKALIUK*, postgraduate student of the Research Institute of Technology and Quality of Animal Products, https://orcid.org/0000-0001-7732-6365

N. I. MARTSENIUK*, undergraduate student of the Faculty of Livestock Raising and Water Bioresources

E-mail: leonora.adamchuk@gmail.com

National University of Life and Environmental Sciences of Ukraine

\begin{abstract}
The strength and development of bee colonies in May, especially those that have weakened after wintering, is not sufficient for the effective use during the first honey harvest in Ukraine.One way to effectively stimulate bee colonies to develop is through the use of carbohydrate protein feedings. The purpose of the study was to investigate the development of bee colonies in the early spring with the use of different types of feeding.The studies were conducted using zootechnical (alignment and assessment of the status of bee colonies, control feeding) and statistical methods of research in the early spring of 2019 in the conditions of Holosiivskaapiary (Kyiv, Ukraine).The control group classic maintenance, similar to all apiary colonies. The research group - was applied the developed scheme of early spring feeding and training of bees. For feeding, honeybeebread dough, bee pollen in the form of flour, monofloral bee pollen candy were used. After the first feeding, the experimental colonies outweighed the control ones by 0.3 rows in strength, $0.5 \mathrm{comb}$ by the number of open brood combs and $0.43 \mathrm{comb}$ by the sealed ones as well as by 1.3 comb of fodder ( $5.3 \mathrm{~kg}$ ). After the second feeding, the experimental colonies outweighed the control ones by 1.6 rows in strength, 1.5 comb by the number of open brood combs, were the same by the number of sealed sells and outweighed
\end{abstract}

* Scientific supervisor - L. O. Adamchuk, Candidate of Agricultural Sciences 
by 0.3 honeycomb in the number of fodder. During the evaluation it was found that the experimental colonies outweighed the controlled ones instrength by 2 rows, by 0.5 in open and by 1 comb in sealed brood combs as well as by 0.5 honeycomb of fodder $(2 \mathrm{~kg})$. It was found that a complex three-stage carbohydrate-protein feeding of weak bee colonies (5-6 combs) after wintering makes it possible to increase their strength to 10 combs by early May.

Keywords: honey dough, candy, sugar syrup, bee brood

\section{Introduction.}

Due to global climate change, the flowering time of plants, which have been the main sources of bee pollen for bees, is shifting. The flowering of Robiniapseudoacacia has shifted from June to May. However, the strength of bee colonies development in May is not sufficient for effective use of black locust for honey harvest. Therefore, studying the effectiveness of ways to build the strength of bee colonies to harvest pollen from black locust is a relevant area of research.

\section{Analysis of recent research and publications.}

The development of bee colonies is closely related to the presence of forage in nature. Therefore, optimizing feed intake in the nest can stimulate or suspend colony development. The organization of an optimal (uninterrupted) nectar conveyer is important (Boiarchuk, 2015).

However, in the absence of feed sources in nature or its poor quality, the bees are fed with carbohydrate and protein feeds. The positive effect of protein feeding on the spring growth of bee colonies and their preparation for effective use of honey harvest has been proved (Mishchenko \& Lytvynenko, 2017). It has been found that feeding bees with sugar syrup with the addition of 5\% full-cream milk increases the rate of development of colonies by $40.4 \%$ of growth of bee colonies during preparation for wintering (Prudnikov, 2018).

Scientists have investigated the effectiveness of feeding bees with different carbohydrate diets in the summer. It was found that the additional feeding of bees with $30 \%$ sugar syrup causes an increase in the activity of catalase, and $30 \%$ solutions of glucose or fructose - a decrease. Catalase activity was considered to be an indicator of the general state of the bee's antioxidant system (Yazlovytska et al., 2016). It is established that feeding bees with the addition of citrate metals has a positive effect on the internal metabolism of their body, that is, promotes its development.

Thus, known results lead to a corrective effect on the distribution and transformation of lipids in the body of bees, which is caused by the addition of citrates of $\mathrm{Co}$ and $\mathrm{Ni}$ (Pashchenko et al., 2016). The results of stimulation of oviposition and increase of reproductive ability of queen bees due to feeding with citrates of $\mathrm{Ag}$ and $\mathrm{Cu}$ were obtained (Dvyliuk \& Kovalchuk, 2017).

Feeding safety, synergistic and antagonistic effects on the content of $\mathrm{Ag}, \mathrm{Cu}, \mathrm{Fe}, \mathrm{Zn}$ and $\mathrm{Co}$ in the tissues of the bee organism, have shown the results of feeding the drug "Sumer silver" with sugar syrup (Dvyliuk \& Kovalchuk, 2019). 
Along with this, poor bee feeding causes a number of problems. Thus, it is known that bees fed with transgenic pollen showed increased sensitivity to parasites (Verbelchuk et al., 2017). The spoiled protein feed with the pathogen of Nosema has contributed to the reduction of life expectancy of bees (Yefimenko \& Odnosum, 2015).

Thus, the purpose of the studywas to investigate the development of bee colonies in early spring with the use of feeding. To achieve this goal, the following tasks were set: to develop a scheme and recipes for feeding bees; assess the strength of bee colonies and the availability of feed; evaluate the development of bee colonies by the number of open and sealed broods.

\section{Materials and methods of research.}

The assigned tasks were solved experimentally using zootechnical (alignment and assessment of the status of bee colonies, control feeding, training bees) and statistical methods of research. The studies were conducted in the early spring of 2019 under the conditions of the Holosiivska apiary (Kyiv).

Bee colonies of equal strength (5 rows) were selected for the study. All colonies had the samefeedingconditions and were wintering indoors.
Zootechnical research methods consisted of aligning and assessing the status of bee colonies to form two analogous groups of three bee colonies (Brovarskyi et al., 2017).

The control group - classic maintenance, similar to all apiary colonies. The research group - was applied the developed scheme of early spring feeding and training of bees (Table 1).

Other factors were the same for both groups (environmental and climatic conditions, forage). The data obtained were statistically processed.

Research results. The bees of the study group were fed according to the above scheme (Table 1) and the development of bee colonies was observed. Thus, after the first feeding, during the displacement of beehive hives out of wintering place (01.03.19), the effect of feed stimulation was noticeable. The colonies of the study group made a massive flyover, indicating the active development of colonies.

During the same period, the results of the first evaluation were obtained and are given in Table 2 (Stage 1). During the evaluation it was found that the experimental colonies outweighed the controlled ones in strength by 2 rows, by 0.5 in open and by 1 honeycomb in sealed combs as well as by 0.5 honeycomb of fodder.

Thus, early spring feeding with honey-beebread dough stimulated the ovi-

\section{Scheme of feeding bee colonies of the experimental group}

\begin{tabular}{|l|l|l|l|}
\hline Stage & Date & Feeding type & Feeding method \\
\hline I & 15.02 .19 & $\begin{array}{l}\text { Honey-beebread } \\
\text { dough }\end{array}$ & $\begin{array}{l}\text { Formed loaf in plastic bag over nest frames, 2 kg / } \\
\text { colony }\end{array}$ \\
\hline II & 15.03 .19 & Bee pollen & $\begin{array}{l}\text { ground with an industrial mill bee pollen on a napkin } \\
\text { behind the nest frames, } 2 \mathrm{~kg} / \text { colony }\end{array}$ \\
\hline III & 15.04 .19 & Candy & $\begin{array}{l}\text { formed loaf in a plastic bag over nest frames (2.5 kg } \\
\text { of honey, 0.5 kg of powdered sugar, 0.5 kg of flour } \\
\text { from the monoflore bee pollen (as training). }\end{array}$ \\
\hline
\end{tabular}


position of the queen bees in the experimental colonies and made it possible to replenish the feed stocks.Also, it was visually noticeable that the quality of brood in the experimental colonies was better, it was continuous and without gaps. While control colonies observed uterine missed combs. The age of the queen bees in all colonies was the same -1.5 years.

By the start of the second feeding stage, the winter subsidence had been cleared and the insulation was replaced with a dry one for all colonies, free access to water pads for bees in the apiary area had been provided.In addition, there were placed salt water pads.
With the beginning of flowering of herbaceous pollen sources (Corydalis, Pulmonaria, Ficariaverna, Tussilagofarfara) and bushes (Cornus mas, Salix spp.) in the beekeeping area of apiary bees, all colonies intensively began to grow.

On April 1, 2019, an extension, control review and evaluation of the development of colonies after the second stage of feeding was carried out (Table 2, stage 2).

During the evaluation, it was found that the experimental colonies outweighed the control ones by 1.6 rows in strength, 1.5 comb by the number of open combs, were the same by the num-

\section{Estimation of spring growth of weak bee colonies}

\begin{tabular}{|c|c|c|c|c|c|}
\hline \multirow{2}{*}{ Group } & \multirow[t]{2}{*}{ № of colony } & \multirow{2}{*}{$\begin{array}{c}\text { Colonystrength, } \\
\text { rows }\end{array}$} & \multicolumn{2}{|c|}{$\begin{array}{c}\text { Thenumberofbroods, } \\
\text { combs }\end{array}$} & \multirow{2}{*}{$\begin{array}{r}\text { Fodderhoney } \\
\text { combs, pcs. }\end{array}$} \\
\hline & & & open & sealed & \\
\hline \multicolumn{6}{|l|}{\begin{tabular}{|l|} 
Stage 1 \\
\end{tabular}} \\
\hline \multirow{3}{*}{ Control } & 1 & 5.5 & 0.5 & 1 & 2 \\
\hline & 2 & 6 & 0.5 & 1.2 & 2.5 \\
\hline & 3 & 5.5 & 0.5 & 1 & 2 \\
\hline \multirow{3}{*}{ Experiment } & 4 & 6 & 1 & 1.5 & 3.5 \\
\hline & 5 & 6 & 1 & 1.5 & 3.5 \\
\hline & 6 & 6 & 1 & 1.5 & 3.5 \\
\hline \multicolumn{6}{|l|}{ Stage 2} \\
\hline \multirow{3}{*}{ Control } & 1 & 6 & 1 & 2 & 3 \\
\hline & 2 & 7 & 1 & 2 & 3.5 \\
\hline & 3 & 6 & 1 & 2 & 3 \\
\hline \multirow{3}{*}{ Experiment } & 4 & 8 & 2.5 & 2 & 3.5 \\
\hline & 5 & 8 & 2.5 & 2 & 3.5 \\
\hline & 6 & 8 & 2.5 & 2 & 3.5 \\
\hline \multicolumn{6}{|l|}{ Stage 3} \\
\hline \multirow{3}{*}{ Control } & 1 & 8 & 2 & 2 & 4 \\
\hline & 2 & 8 & 2 & 2 & 4 \\
\hline & 3 & 8 & 2 & 2 & 4 \\
\hline \multirow{3}{*}{ Experiment } & 4 & 10 & 2.5 & 3 & 4.5 \\
\hline & 5 & 10 & 2.5 & 3 & 4.5 \\
\hline & 6 & 10 & 2.6 & 3 & 4.5 \\
\hline
\end{tabular}




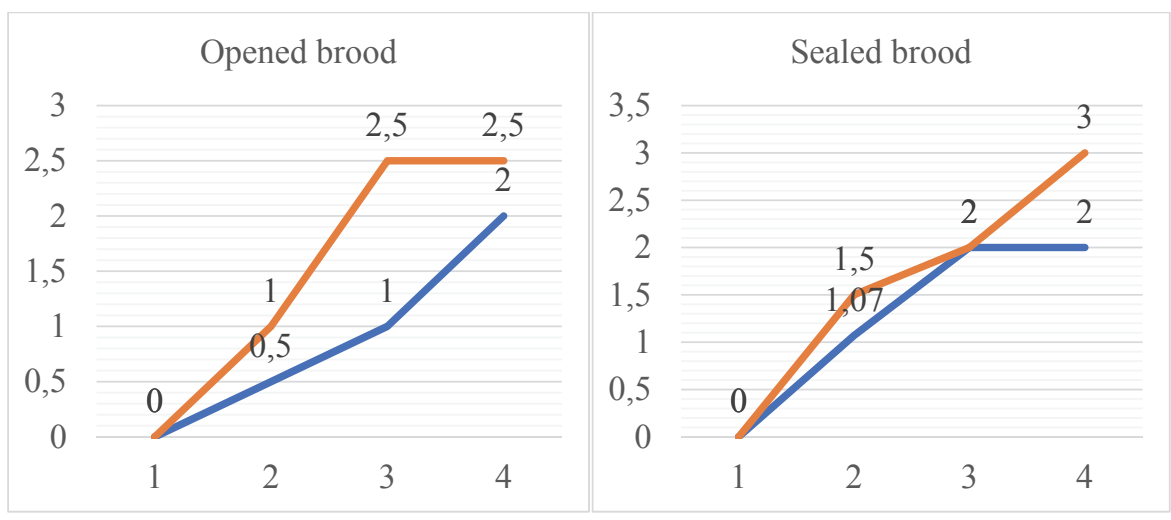

Figure. Number of broods in colonies: - Control; - Experiment

ber of sealed sells and outweighed by 0.3 honeycomb in the number of fodders.

Coloniesthat were not fed were found to be significantly behind in development. On April 15, 2019 re-expansion was carried out, the last stage of feeding started.During the last feeding, one of the bee training methods was applied.Namely, it is known that bees are trained on a particular species by using the syrup infused on the vegetative part and flowers of this plant. We applied this technique to candy.In the recipe of classic candy, 50\% of powdered sugar was substituted for flour of monofloral maple bee pollen. In this way we stimulated bees to search for sources of food with similar smell and taste. On May 1, 2019 a control review was conducted (table 2 , stage 3 ).

During the evaluation it was found that the experimental colonies outweighed the controlled ones in strength by 2 rows, by 0.5 in open and by 1 comb in sealed combs as well as by 0.5 honeycomb of fodder $(2 \mathrm{~kg})$. Thus, in early May, the experimental colonies already occupied the full first housing of 10 combs and were growing better than the colonies without feeding. The dynamics of increasing the number of broods in colonies is shown in the figure.
It was found that the three-stage feeding of bee colonies contributed to the increase in the number of open broods in experimental colonies. Thus, in comparison with the control group, the experimental colonies prevailed on average by $63 \%$ in the number of open brood and by $46 \%$ in the sealed brood.Therefore, the development of weak colonies through stimulation carbohydrate-protein feeding is effective and allows one full bee housing to be obtained by May 1, which will allow them to be used effectively at the first honey harvest at the end of May.

\section{Discussion.}

A complex three-stage carbohydrate-protein feeding of weak bee colonies (5-6 combs) after wintering makes it possible to increase their strength to 10 combs in early May. During May, bees of such a strength can make full use of the natural forage base of the terrain, including the use of black locust honey in late May.In the future, it is necessary to investigate the rate of spring growth of bee colonies due to feeding them probiotic immune-stimulating additives during the formation of forage for the winter. 


\section{Acknowledgments.}

Author Leonora Adamchuk thanks the International Visegrad Fund ID \#51910842 for the scholarship and research internships, during which the results and knowledge presented in this paper were obtained.

The publication was prepared with the active participation of researchers involved in the International network AgroBioNet of the Institutions and researchers for realization of research, education and development program «Agrobiodiversity for improving nutrition, health and life quality» TRIVE (ITMS 26110230085).

\section{References}

1. Boiarchuk, S. V. (2015). Optimization of feed supply to bee colonies. Scientific Bulletin of the National University of Life and Environmental Sciences of Ukraine. Series: Technology of production and processing of livestock products, (223), 57-64.

2. Brovarskyi, V., Brindza, Ja., Otchenashko, V., Povoznikov, M., Adamchuk, L. (2017). Methods of research in beekeeping. 166. ISBN 978-966-2622-26-3

3. Verbelchuk, T. V., P'iaskivskyi, V. M., Verbelchuk, S. P. (2017).Transgenes and their effects on biological objects. Organik, 223-229.

4. Dvylyuk, I. I., \& Kovalchuk, I. I. (2019). The effect of the drug "Sumer silver" on the viability of honey bees and the content of individual trace elements in their body. Bioresources and environmental management, 11 (1-2), 7.

5. Dvylyuk, I. I., \& Kovalchuk, I. I. (2017). Reproductive ability of queen bees under conditions of feeding with citrate of argentum and cuprum. Animal Biology, 19 (2). 30-36 http://doi.org/10.15407/animbiol19.02.030

6. Yefimenko, T. M., \&Odnosum, H. V. (2015). Effect of feeding on pollen and bee bread on bees for nosematosis. Scientific Bulletin of the National University of Life and Environmental Sciences of Ukraine. Series: Technology of production and processing of livestock products, (223), 103-107

7. Mishchenko, O. A., \&Lytvynenko, O. M. (2017). Influence of protein feeding on the spring extension of bee colonies and their preparation for effective use of honeycomb. Beekeeping of Ukraine,(2), 152-158.

8. Pashchenko, A. H., Kovalchuk, I. I., \&Romaniv, L. I. (2016). The content of lipids in the tissues and bee products when fed in the spring with $\mathrm{Co}$ and $\mathrm{Ni}$ citrates. Animal Biology, (18) 4, 174-174.

9. Prudnikov, V. H. (2018). The effectiveness of different ways to prepare bee colonies for wintering. Scientific Bulletin of the National University of Life and Environmental Sciences of Ukraine. Series: Technology of production and processing of livestock products, (271), 244-248.

10. Yazlovytska, L. S., Kosovan, M. D., Cherevatov, V. F., \& Volkov, R. A. (2016). The activity of Apis mellifera L. catalase during summer feeding with a different carbohydrate diet. Biological systems, (8) 2, 182-188.

Л. О. Адамчук, С. В. Боярчук, К. В. Лавріненко, Р. М. Двикалюк, Н. І. Марценюк (2019). РОЗВИТОК БДЖОЛИНИХ СІМЕЙ ВНАСЛІДОК РАННЬОВЕСНЯНОЇ ПІДГОДІВЛІЗА РОЗРОБЛЕНОЮ СХЕМОЮ. ANIMAL SCIENCE AND FOOD TECHNOLOGY, 10(2): 5-11. https://doi.org/10.31548/animal2019.02.005

Анотація: Сила і розвиток бджолиних сімей у травні, особливо тих, що ослабли після зимівлі, не достатня для ефективного використання першого медозбору в умовах Укра- 
їни. Одним із способів ефективного стимулювання бджолиних сімей до розвитку $\epsilon$ використання вуглеводно-білкових підгодівель. Метою роботи було дослідити розвиток бджолиних сімей у ранньовесняний період із застосуванням підгодівлі. Дослідження проводили з використанням зоотехнічних (вирівнювання та оцінка стану бджолиних сімей, контрольна підгодівля, дресерування) та статистичних методів дослідження у ранньовесняний період 2019 року в умовах Голосіївської пасіки (м. Київ, Україна). Контрольна група - класичне утримання, подібне до всіх сімей пасіки. Дослідна група -застосовували розроблену схему ранньовесняної годівлі і дресирування бджіл. Для підгодівлі застосовували медово-пергове тісто, бджолине обніжжя в стані борошна, канді з монофлорного бджолиного обніжжя (як елемент дресирування). Після першої підгодівлі дослідні сім'ї за силою переважали контрольні на 0,3 вулички, за кількістю відкритого стільника переважали на 0,5, а запечатаного - на 0,43 стільника, за кількістю кормів переважали на 1,3 стільника (5,3 кг). Після другої підгодівлі дослідні сім'ї за силою переважали контрольні на 1,6 вулички, за кількістю відкритого - 1,5 стільника, за кількістю критого розплоду були однаковими, за кількістю кормів переважали на 0,3 стільника (1,3 кг). Під час оцінювання встановили, що дослідні сім'ї за силою в кінці експерименту переважали контрольні на 2 вулички, за кількістю відкритого - на 0,5, а запечатаного - на 1 стільник, за кількістю кормів - на 0,5 стільника (2 кг). Встановили, що комплексна триетапна вуглеводно-білкова підгодівля слабких бджолиних сімей (5-6 стільників) після зимівлі дає можливість наростити їх силу до 10 стільників на початок травня.

Ключові слова: медове тісто, канді, цукровий сироп, розплід бджіл 